J. Perinat. Med. $10(1982) 42$

\title{
The Ponderal Index as a measure of the nutritional status at birth and its relation to some aspects of neonatal morbidity
}

\author{
F. J. Walther, L. H. J. Ramaekers
}

Dept. of Neonatology, St. Annadal Hospital, University of Limburg, Maastricht, The Netherlands

\section{Introduction}

Intrauterine malnutrition is generally defined by low birthweight for a gestational age calculated from the last normal period and corroborated by clinical assessment of the infant at birth [16]. However, not all infants affected by intrauterine malnutrition will be included in such a definition as an unknown percentage of newborns whose birthweight does not fall below the normal for gestational age, have not achieved their full growth potential [3]. Clinically these infants will be recognized by manifest soft tissue loss, usually called 'wasting'.

To facilitate the diagnosis of intrauterine malnutrition at birth it is useful to incorporate body length in the assessment and to calculate ROHRER's ponderal index $\left(100 \times \mathrm{W} / \mathrm{L}^{3}\right)$ which assesses whether an infant appears relatively 'fat' or 'thin' by quantification of the dissociation of weight and length $[3,12]$. Wasted infants will show a relatively small ponderal index irrespective of their distribution on the percentile lines of birthweight for gestational age. LuBCHENCO et al. [9] and MILleR and HASSANEIN [11] provided standard curves of the ponderal index (P.I.) for gestational age. Since GRUENWALD [3] widely explained its benefits several authors have used the P.I. as criterion to define the state of nutrition of their study groups. These studies have demonstrated that the P.I. at birth is correlated with skinfold thickness [11], skeletal retardation $[13,17]$, postnatal growth $[1,17]$ and behavior problems and neurological dysfunction at pre-school age [18].
It is known that small-for-gestational age (S.G.A.) infants (whose birthweight is below the 10th percentile for gestational age) have a higher incidence of asphyxia, hypoglycemia [10], hypothermia [14], and hyperviscosity [4, 19] in the neonatal period. Unlike birthweight the relation between the P.I. (as a quantitative measure of the nutritional status at birth) and neonatal morbidity has not yet been properly evaluated. For that purpose the incidence of 6 common neonatal problems (asphyxia, acidosis, hypothermia, hypoglycemia, hyperviscosity, and hyperbilirubinemia) was examined in a group of 'unselected' term infants in relation to birthweight and to P.I. distribution.

\section{Materials and methods}

The subjects in this study consisted of 500 consecutive live-born infants admitted to the neonatal ward directly after birth. All were Caucasian singletons born at a gestational age between 38 and 42 weeks, as verified by the Dubowitz score [2]. Excluded were infants of diabetic mothers, infants with $\mathrm{Rh}$ or $\mathrm{ABO}$ hemolytic disease, and infants with fetal diseases (congenital infections and anomalies, chromosomal aberrations). $55 \%$ of the infants were admitted for observation after an artificial delivery, $22 \%$ because of signs of intrauterine malnutrition, $8 \%$ because of overweight, and $15 \%$ for a variety of reasons.

Weight and length were measured after birth using methods previously described [12]. Of each infant 
the percentile of birthweight for gestational age was established allowing for sex and birth order [7]. Furthermore the P.I. (100X weight in grams/ length ${ }^{3}$ in $\mathrm{cm}$ ) was calculated for each infant and its distribution on the percentile charts of MILLER and HASSANEIN [11] was established.

The next information of all infants was collected: APGAR scores at 1 and 5 minutes after birth; arterial umbilical $\mathrm{pH}$; rectal temperature at admission; blood glucose levels at 1, 2, 3, 6, 12, 24 and 48 hours after birth; venous haematocrit levels if capillary haematocrit values from a pre-warmed heel amounted to $70 \%$ or more at 1 and/or 3 hours after birth [17]; and serum bilirubin levels in case of neonatal jaundice. The variables assessed in this study were defined as follows. Neonatal asphyxia was diagnosed in infants who had an APGAR score of $0-3$ at 1 and/or 5 minutes and required at least one minute of positive pressure ventilation before respiration occurred. Acidosis was defined as an arterial umbilical $\mathrm{pH}<7.09$ [5]. Hypothermia was defined as an admission rectal temperature $<35.5{ }^{\circ} \mathrm{C}$. Hypoglycemia was defined as a blood sugar concentration $\leqslant 1.6 \mathrm{mmol} / \mathrm{l}$. Hyperviscosity was defined as a venous haematocrit $\geqslant 65 \%$. Hyperbilirubinemia was defined as a total bilirubin concentration $>200 \mu \mathrm{mol} / 1$. As a routine clamping of the umbilical cord took place before 1 minute after birth of the infants. All vital problems were managed by a paediatrician in the delivery room. All infants in the study were subjected to an early feeding practice. The distribution of discrete variables were compared by chisquare.

\section{Results}

The distribution of the infants by birthweight for gestational age and by P.I. is presented in Tab. I. The distribution by birthweight differs significantly from the distribution by ponderal index. Whereas 119 of the 500 (23.8\%) infants had a birthweight below the 10th percentile for gestational age (and were S.G.A.), only 80 of the 500 (16.0\%) infants had a P.I. below the 10 th percentile (and were wasted). As 46 of the 500 (9.2\%) infants had both a birthweight and a P.I. below the 10th percentiles, there exists a firm correlation between these two parameters $\left(\mathrm{X}^{2}=\right.$ $59.639, \mathrm{DF}=1, \mathrm{p}<0.0005)$.

$73 / 119(61.3 \%)$ S.G.A. infants had a P.I. on or above the 10th percentile and were not severily wasted. 34 Infants had a P.I. below the 10th percentile and a birthweight on or between the 10 th and 90 th percentiles, indicating that $8.1 \%$ of the A.G.A. (appropriate-for-gestational age) infants were clinically wasted.

Tab. II shows that asphyxia $\left(\mathrm{X}^{2}=12.921, \mathrm{DF}=5\right.$, $\mathrm{p}<0.025)$, acidosis $\left(\mathrm{X}^{2}=11.674, \mathrm{DF}=5\right.$, $\mathrm{p}<0.05)$, hypoglycemia $\left(\mathrm{X}^{2}=14.671, \mathrm{DF}=5\right.$, $\mathrm{p}<0.025)$, hypothermia $\left(X^{2}=37.221, \mathrm{DF}=5\right.$, $\mathrm{p}<0.0005)$, and hyperviscosity $\left(\mathrm{X}^{2}=17.235\right.$, $\mathrm{DF}=5, \mathrm{p}<0.005$ ) were significantly more often diagnosed in infants with a small P.I. A statistically significant correlation between the P.I. and hyperbilirubinemia was absent. As 11 of the 42 infants with asphyxia also presented acidosis, a significant correlation between acidosis and asphyxia could be established $\left(\mathrm{X}^{2}=15.845, \mathrm{DF}=1\right.$, $\mathrm{p}<0.005)$.

Tab. I. Distribution of the study group on the percentile charts of birthweight and of the ponderal index (percentages).

\begin{tabular}{|c|c|c|c|c|c|c|c|}
\hline $\begin{array}{c}\begin{array}{c}\text { Birth- } \\
\text { weight }\end{array} \\
-\end{array}$ & $<10$ & $10-25$ & $26-50$ & $51-75$ & $76-90$ & $>90$ & $\begin{array}{l}\text { Total } \\
(100 \%)\end{array}$ \\
\hline $\begin{array}{l}<10 \\
10-25 \\
26-50 \\
51-75 \\
76-90 \\
>90\end{array}$ & $\begin{array}{r}46 \\
24 \\
29 \\
15 \\
3 \\
2\end{array}$ & $\begin{array}{r}22 \\
23 \\
37 \\
25 \\
4 \\
3\end{array}$ & $\begin{array}{r}5 \\
16 \\
33 \\
20 \\
7 \\
2\end{array}$ & $\begin{array}{r}5 \\
9 \\
30 \\
33 \\
8 \\
8\end{array}$ & $\begin{array}{r}1 \\
1 \\
7 \\
23 \\
12 \\
7\end{array}$ & $\begin{array}{r}1 \\
1 \\
2 \\
16 \\
8 \\
12\end{array}$ & $\begin{array}{rr}80 & (16.0 \%) \\
74 & (14.8 \%) \\
138 & (27.6 \%) \\
132 & (26.4 \%) \\
42 & (8.4 \%) \\
34 & (6.8 \%)\end{array}$ \\
\hline Total $(100 \%)$ & $\begin{array}{l}119 \\
(23.8 \%)\end{array}$ & $\begin{array}{l}114 \\
(22.8 \%)\end{array}$ & $\begin{array}{l}83 \\
(16.6 \%)\end{array}$ & $\begin{array}{l}93 \\
(18.6 \%)\end{array}$ & $\begin{array}{l}51 \\
(10.2 \%)\end{array}$ & $\begin{array}{l}40 \\
(8.0 \%)\end{array}$ & 500 \\
\hline
\end{tabular}


Tab. II. Distribution of neonatal morbidity on the percentile blocks of the ponderal index:(percentages of the percentile blocks).

\begin{tabular}{|c|c|c|c|c|c|c|c|}
\hline $\begin{array}{l}\text { Neo- } \\
\text { natal } \\
\text { morbidity }\end{array}$ & $\begin{array}{l}<10 \\
n=80\end{array}$ & $\begin{array}{l}10-25 \\
n=74\end{array}$ & $\begin{array}{l}26-50 \\
n=138\end{array}$ & $\begin{array}{l}51-75 \\
n=132\end{array}$ & $\begin{array}{l}76-90 \\
n=42\end{array}$ & $\begin{array}{l}>90 \\
n=34\end{array}$ & $\begin{array}{l}\text { Total } \\
n=500\end{array}$ \\
\hline $\begin{array}{l}\text { Asphyxia } \\
\text { Acidosis } \\
\text { Hyperviscosity } \\
\text { Hypoglycemia } \\
\text { Hy pothermia } \\
\text { Hyperbilirubinemia }\end{array}$ & $\begin{array}{rr}14 & (17.5) \\
15 & (18.7) \\
10 & (12.5) \\
7 & (8.7) \\
19 & (23.7) \\
4 & (5.0)\end{array}$ & $\begin{array}{ll}6 & (8.1) \\
7 & (9.4) \\
9 & (12.2) \\
1 & (1.3) \\
5 & (6.7) \\
0 & (0)\end{array}$ & $\begin{aligned} 11 & (8.0) \\
10 & (7.2) \\
9 & (6.5) \\
2 & (1.4) \\
7 & (5.1) \\
10 & (7.2)\end{aligned}$ & $\begin{aligned} 9 & (6.8) \\
10 & (7.6) \\
1 & (0.7) \\
4 & (3.0) \\
6 & (4.5) \\
11 & (8.3)\end{aligned}$ & $\begin{array}{ll}2 & (4.8) \\
3 & (7.1) \\
1 & (2.4) \\
4 & (9.5) \\
1 & (2.4) \\
3 & (7.1)\end{array}$ & $\begin{array}{ll}0 & (0) \\
1 & (2.9) \\
2 & (5.9) \\
0 & (0) \\
0 & (0) \\
0 & (0)\end{array}$ & $\begin{array}{ll}42 & (8.4) \\
46 & (9.2) \\
32 & (6.4) \\
18 & (3.6) \\
38 & (7.6) \\
28 & (5.6)\end{array}$ \\
\hline
\end{tabular}

Tab. III. Distribution of neonatal morbidity on the percentile blocks of birthweight for gestational age (percentages of the percentile blocks).

\begin{tabular}{|c|c|c|c|c|c|c|c|}
\hline $\begin{array}{l}\text { Neo- } \\
\text { natal } \\
\text { morbidity }\end{array}$ & $<10$ & $10-25$ & $26-50$ & $51-75$ & $76-90$ & $>90$ & total \\
\hline $\begin{array}{l}\text { Asphyxia } \\
\text { Acidosis } \\
\text { Hyperviscosity } \\
\text { Hypoglycemia } \\
\text { Hypothermia } \\
\text { Hyperbilirubinemia }\end{array}$ & $\begin{array}{rr}17 & (14.3) \\
15 & (12.6) \\
23 & (19.3) \\
5 & (4.2) \\
22 & (18.5) \\
6 & (5.0)\end{array}$ & $\begin{array}{rr}6 & (5.3) \\
12 & (10.5) \\
4 & (3.5) \\
4 & (3.5) \\
11 & (9.6) \\
4 & (3.5)\end{array}$ & $\begin{array}{lr}9 & (10.8) \\
6 & (7.2) \\
3 & (3.6) \\
2 & (2.4) \\
2 & (2.4) \\
5 & (6.0)\end{array}$ & $\begin{array}{ll}4 & (4.3) \\
3 & (3.2) \\
1 & (1.1) \\
2 & (2.1) \\
2 & (2.1) \\
9 & (9.7)\end{array}$ & $\begin{array}{ll}3 & (5.9) \\
6 & (11.8) \\
1 & (2.0) \\
0 & (0) \\
1 & (2.0) \\
2 & (3.9)\end{array}$ & $\begin{array}{ll}3 & (7.5) \\
4 & (10.0) \\
0 & (0) \\
5 & (12.5) \\
0 & (0) \\
2 & (5.0)\end{array}$ & $\begin{array}{ll}42 & (8.4) \\
46 & (9.2) \\
32 & (6.4) \\
18 & (3.6) \\
38 & (7.6) \\
28 & (5.6)\end{array}$ \\
\hline
\end{tabular}

Infants whose birthweight for gestational age is low, had a higher incidence of hypoglycemia $\left(\mathrm{X}^{2}=\right.$ 12.327, $\mathrm{DF}=5, \mathrm{p}<0.05)$, hypothermia $\left(\mathrm{X}^{2}=\right.$ $33.484, \mathrm{DF}=5, \mathrm{p}<0.0005)$ and hyperviscosity $\left(\mathrm{X}^{2}=44.680, \mathrm{DF}=5, \mathrm{p}<0.0005\right)$, (Tab. III). Asphyxia, acidosis, and hyperbilirubinemia were not significantly related to low birthweight infants, though the incidence of asphyxia was slightly higher in S.G.A. infants.

One or more of the 6 investigated neonatal problems were diagnosed in 57/119 (47.9\%) S.G.A. infants, in $41 / 80(51.2 \%)$ infants with a P.I. below the 10th percentile, and in $30 / 46(65.2 \%)$ infants whose birthweight and P.I. fell below the 10th percentiles.

Tab. IV points out that in general infants with a birthweight and a P.I. below the 10th percentiles showed more often neonatal problems than wasted A.G.A. infants and non-wasted S.G.A. infants.
Tab. IV. Neonatal morbidity in 3 subgroups (percentages).

\begin{tabular}{|c|c|c|c|}
\hline $\begin{array}{l}\text { Neonatal } \\
\text { morbidity }\end{array}$ & $\begin{array}{l}\text { P.I. and } \\
\text { birthweight } \\
<10 \text { th } \\
\text { percentiles }\end{array}$ & $\begin{array}{l}\text { P.I. }<10 \text { th } \\
\text { percentile } \\
\text { and } \\
\text { birthweight } \\
\geqslant 10 \text { th } \\
\text { percentile }\end{array}$ & $\begin{array}{l}\text { Birthweight } \\
<10 \text { th } \\
\text { percentile } \\
\text { and P.I. } \\
\geqslant 10 \text { th } \\
\text { percentile } \\
n=73\end{array}$ \\
\hline Asphyxia & $10(21.7)$ & $4(11.8)$ & $7 \quad(9.6)$ \\
\hline Acidosis & 11 (23.9) & $4(11.8)$ & $4 \quad(5.5)$ \\
\hline $\begin{array}{l}\text { Hyper- } \\
\text { viscosity }\end{array}$ & $8(17.4)$ & $2 \quad(5.9)$ & $15^{\circ}(20.5)$ \\
\hline $\begin{array}{l}\text { Hypo- } \\
\text { glycemia }\end{array}$ & $4 \quad(8.7)$ & $(8.8)$ & $1 \quad(1.4)$ \\
\hline $\begin{array}{l}\text { Hypo- } \\
\text { thermia }\end{array}$ & $16(34.8)$ & $3 \quad(8.8)$ & $6 \quad(8.2)$ \\
\hline $\begin{array}{l}\text { Hyper- } \\
\text { bilirubinemia }\end{array}$ & $3(6.5)$ & $\begin{array}{l}1 \quad(2.9) \\
\quad,\end{array}$ & $3 \quad(4.1)$ \\
\hline
\end{tabular}


Hyperviscosity is an exception to this rule as it was more often seen in both wasted and non-wasted S.G.A. infants. Hyperbilirubinemia centred around the 50th percentiles of both birthweight and the ponderal index and its incidence was not increased in any of the 3 subgroups defined above.

\section{Discussion}

Except the indicated limitations, assessment of fetal growth by means of birthweight for gestational age regularly throws up problems in daily practice. For example insufficient information about the gestational age may hamper the interpretation of birthweight, whereas infants of different race, sex, and birthrank cannot be compared without the consultation of different standard graphs of intrauterine growth. The use of the ponderal index may then be of great help as it is relatively independent of race, sex, birthrank, and gestational age at term [11]. As the P.I. also points to wasted infants whose birthweight is appropriate for gestational age (about $8 \%$ in this study) and quantifies intrauterine malnutrition, its advantages are obvious in daily practice. However, birthweight for gestational age has yielded important information about the relationship between intrauterine growth retardation and neonatal morbidity and mortality. It continues therefore to deserve its place in the classification of infants at birth. In need of more information about the nutritional status at birth it is advantageous to consider the P.I.

Of the six neonatal problems assessed in this study only hypoglycemia has been analysed in relation to the P.I. before. JÁRAI et al. [6] investigated a mixed group of preterm, term, and postterm S.G.A. infants using different indices of body proportions and pointed to the significance of

\section{Summary}

The purpose of this study was to investigate if the ponderal index might be a better measure to predict neonatal morbidity than birthweight for gestational age. The ponderal index $\left(100 \times \mathrm{W} / \mathrm{L}^{3}\right)$ assesses whether an infant appears relatively 'fat' or 'thin' at birth by quantification of the dissociation of weight and length and is of great soft tissue wasting (rather than low birthweight for gestational age itself) in the development and diagnosis of neonatal hypoglycemia. The same conclusion emerges from this study. But it also shows that hypoglycemia occurred often in overweight infants (P.I. $>75$ th percentile and/or birthweight $>90$ th percentile) whose mothers were free from diabetes. The cause of this phenomenon remained unclear.

Generally speaking it can be said that the P.I. is equal to or surpasses birthweight for gestational age as a tool to predict neonatal problems like asphyxia, acidosis, hypoglycemia, and hypothermia. Though hyperviscosity is more common in infants with a small P.I., it occurs especially in those infants whose birthweight falls below the 10 th percentile. A.proper explanation of this fact is unknown to us and will need further study.

Though low values of the arterial umbilical $\mathrm{pH}$ correlated well with a low APGAR score (as shown by HuISJEs and AARNOUDSE in a recent study [5]) and the necessity of positive pressure ventilation, this relation was not complete as only one fourth of the asphyxia cases presented with severe acidosis and the other way round. This phenomenon has been laid down in a publication of LITSCHGI et al. [8] who described that especially the combination of a low APGAR score and acidosis resulted in an increased incidence of neurological morbidity. As this combination was mostly diagnosed in the underweight infants who were wasted, this group will be at high risk of developmental problems as a result of this problem. Hyperbilirubinemia is relatively rare in wasted and underweight infants. This is probably due to an advanced stage of functional maturity of the liver post partum brought on by a large blood volume and a higher haematocrit [15].

help to recognize wasted infants irrespective of their distribution on the percentile lines of birthweight for gestational age. Except that the ponderal index is more informative about the nutritional status at birth, it is relatively independent of race, sex, birthrank, and gestational age at term [11]. Therefore the ponderal index is 
an easier tool for rapid diagnosis of intrauterine malnutrition at birth than birthweight for gestational age. The relation between the ponderal index and neonatal morbidity and between birthweight and neonatal morbidity was studied in a group of 500 term infants of various birthweight. The distribution of the infants by birthweight differed significantly from the distribution by ponderal index (Tab. I): whereas their average birthweight centred around the 25 th percentile [7], their average ponderal index centred close by the 45 th percentile [11]. One third of the S.G.A. infants and $8 \%$ of the A.G.A. infants were wasted. 6 common neonatal problems were investigated: asphyxia, acidosis, hypoglycemia, hypothermia, hyperviscosity and hyperbilirubinemia. Asphyxia, acidosis, hypoglycemia, hypo- thermia, and hyperviscosity , were significantly more frequently diagnosed in (wasted) infants with a small ponderal index, (Tab. II), whereas only hypoglycemia, hypothermia, and hyperviscosity could be related to a low birthweight for gestational age, (Tab. III). Especially the combination of wasting and underweight pointed to a high incidence of neonatal morbidity (Tab. IV). Hyperbilirubinemia was rare in both wasted and underweight infants.

It seems warrantable to conclude that like birthweight the ponderal index is a reliable measure of neonatal morbidity. Therefore the calculation of the ponderal index at birth deserves a place beside the estimation of birthweight for gestational age.

Keywords: Intrauterine malnutrition, neonatal morbidity, ponderal index, term newborns.

\section{Zusammenfassung}

Der Gewichtsindex als Maß für den Ernährungszustand bei der Geburt und seine Bedeutung für die neonatale Morbidität

Ziel unserer Untersuchung war zu bestimmen, ob der Gewichtsindex einen besseren Parameter zur Vorhersage der neonatalen Morbidität darstellt als das Geburtsgewicht bezogen auf das Gestationsalter. Der Gewichtsindex (100 X Gewicht/Länge ${ }^{3}$ ) sagt aus, ob ein Kind bei der Geburt relativ ,dick' oder, dünn' ist, indem die Dissoziation zwischen Gewicht und Länge quantifiziert wird. So können schwächliche Kinder erkannt werden, und zwar unabhängig von den Verteilungskurven, in denen das Geburtsgewicht auf das Schwangerschaftsalter bezogen wird. Der Gewichtsindex ist aber nicht nur aussagekräftiger bezüglich des Ernährungszustandes, sondern auch unabhängig von der Rasse, dem Geschlecht, der Anzahl der Geburten und der Schwangerschaftsdauer zum errechneten Termin [11]. Aus diesen Gründen stellt der Gewichtsindex einen geeigneteren Parameter zur postpartalen Diagnose einer intrauterinen Mangelernährung dar als das Gewicht bezogen auf das Schwangerschaftsalter.

Die Beziehung zwischen Gewichtsindex und neonataler Morbidität einerseits und zwischen Geburtsgewicht und neonataler Morbidität auf der anderen Seite wurde an 500 am Termin entbundenen Kindern mit unterschiedlichen Geburtsgewichten untersucht. Die Verteilung hinsichtlich des Geburtsgewichtes unterschied sich signifi- kant von der Verteilung bezogen auf den Gewichtsindex (Tab. I): während sich das durchschnittliche Geburtsgewicht in der Nähe der 25er Perzentile befand [7], lag der mittlere Gewichtsindex nahe der 45er Perzentile [11]. Ein Drittel der Small for date-Kinder und 8\% der Appropriate for date-Kinder waren als schwächlich zu bezeichnen. Wir untersuchten 6 der häufiger vorkommenden neonatalen Komplikationen: Asphyxie, Azidose, Hypoglykämie, Hypothermie, Hyperviskosität und Hyperbilirubinämie. Davon wurden die Asphyxie, Azidose, Hypoglykämie, Hypothermie und Hyperviskosität signifikant häufiger in der Gruppe der (schwächlichen) Kinder mit einem niedrigen Gewichtsindex diagnostiziert (Tab. II). Setzte man statt des Gewichtsindex das Geburtsgewicht ein, so ergab sich lediglich eine Häufung von Hypoglykämien, Hypothermien und Hyperviskosität in Bezug auf ein für das Schwangerschaftsalter zu geringes Gewicht (Tab. III). Speziell die Kombination von niedrigem Gewichtsindex und Untergewicht wies auf eine hohe neonatale Morbiditätsrate hin (Tab. IV), was aber nicht für die Hyperbilirubinämie galt. Wir meinen aus unseren Untersuchungen schließen zu können, daß der Gewichtsindex ebenso wie das Geburtsgewicht ein verläßlicher Parameter für die neonatale Morbiditätsrate ist. Darum sollte der Berechnung des Gewichtsindex ein Platz neben der Schätzung des Geburtsgewichtes bezogen auf das Gestationsalter eingeräumt werden.

Schlüsselwörter: Gewichtsindex, intrauterine Mangelernährung, neonatale Morbidität, Neugeborene am Termin.

\section{Résumé}

Mesure de l'etat nutritionnel a la naissance par l'index ponderal - relations de cet index avec quelques aspect de la morbidite neonatale

Le but de cette étude a été de réchercher si l'index pondéral pouvait être une meilleure mesure pour prévoir la morbidité néonatale que le poids de naissance en fonction de l'âge gestationnel. L'index pondéral (100 X $\mathrm{W} / \mathrm{L}^{3}$ ) détermine si un enfant à la naissance est relativ- ement "gros" ou "maigre" en quantifiant la part du poids et de la taille; l'index offre une grande aide pour reconnaître les enfants dénutris sans tenir compte de leur répartition par rapport aux courbes de percentiles du poids de naissance pour l'âge gestationnel. En dehors du fait que l'index pondéral offre plus d'informations sur l'état nutritionnel à la naissance, il est relativement indépendant de la race, du sexe, de la parité et de l'age 
gestationnel à terme [11]. De plus, l'index pondéral est un moyen plus commode pur porter rapidement à la naissance le diagnostic de malnutrition intra-utérine que le poids de naissance rapporté à l'âge gestationnel. Les auteurs ont étudié sur une population de 500 enfants à terme de poids de naissance variés les relations entre l'index pondéral et la morbidité néonatale d'une part et entre le poids de naissance et la morbidité néonatale d'autre part. La répartition des enfants en fonction du poids de naissance est significativement différente de la répartition en fonction de l'index pondéral (Tab. I): en effet, la moyenne des poids de naissance se situe autour du 25 ème percentile [7] alors que la moyenne des index pondéraux est autour du 45ème [11] - Un tiers des enfants hypotrophiques et $8 \%$ des normaux étaient dénutris. Les auteurs ont étudiés 6 éléments néonataux usuels: l'asphyxie, l'acidose, l'hypoglycémie, l'hypo- thermie, l'hyperviscosité et l'hyperbilirubinémie. Les 5 premiers éléments ont été retrouvés avec une fréquence significativement plus élevée chez les enfants (dénutris) présentant un index pondéral faible (Tab. II), alors que seules l'hypoglycémie, l'hypothermie et l'hyperviscosité ont été trouvées en relation avec un faible poids de naissance pour l'âge gestationnel (Tab. III). Fait important: l'association dénutrition-faible poids présente une grande incidence de morbidité néonatale (Tab. IV). L'hyperbilirubinémie est rare, que ce soit chez les enfants dénutris ou chez les enfants de faible poids.

Il apparaît autorisé de conclure que l'index pondéral est un paramètre représentatif de la morbidité périnatale au même titre que le poids de naissance. La détermination de l'index pondéral à la naissance a son intérêt à côte de l'estimation du poids en fonction de l'âge gestationnel.

Mots-clés: Malnutrition intra-utérine, morbidité néonatale index pondéral, nouveau-nés à terme.

\section{Bibliography}

[1] Davies, D. P., P. Platts, J. M. Pritchard, P. W. WILKINSON: Nutritional status of light-fordate infants at birth and its influence on early postnatal growth. Arch. Dis. Childh. 54 (1979) 703

[2] Dubowitz, L., V. DUBowITZ, C. GoldBERG: Clinical assessment of gestational age in the newborn infant. J. Pediatr. 77 (1970) 1

[3] GRUENWALD, P.: Pathology of the deprived fetus and its supply line. In: Size at birth. 27th Ciba Fdn. Symp. 1974

[4] HAKANSON, D. O., W. OH: Hyperviscosity in the small-for-gestational age infant. Biol. Neonate 37 (1980) 109

[5] HUISJES, H. J., J. G. AARNOUDSE: Arterial or venous umbilical $\mathrm{pH}$ as a measure of neonatal morbidity? Early Hum. dev. 3 (1979) 155

[6] JÅRAI, I., J. MESTYÁN, K. SCHULTZ, A. LÁZAR, M. HALÁSZ, I. KRASSY: Body size and neonatal hypoglycemia in intrauterine growth. retardation. Early Hum. Dev. 1 (1977) 25

[7] KLOOSTERMAN, G. J.: On intrauterine growth. The significance of prenatal care. Int. J. Gynaec. Obstet. 8 (1970) 895

[8] LITSCHGI, M., J. J. BEUZ, E. GLATTHAAR: Aktuelle und prognostische Bedeutung des arteriellen Nabelschnur-pH für die postpartale Zustandsdiagnostik. Z. Geburtsh. Perinat. 178 (1974) 23

[9] LUBCHENCO, L. O., C. HANSMAN, E. BOYD: Intrauterine growth in length and head circumference as estimated from live births at gestational ages from 26 till 42 weeks. Pediatrics 37 (1966) 403

[10] LUBCHENCO, L. O., H. BARD: Incidence of hypoglycemia in newborn infants classified by birthweight and gestational age. Pediatrics 47 (1971) 831
[11] MILLER, H. C., K. HASSANEIN: Diagnosis of impaired fetal growth in newborn infants. Pediatrics 48 (1971) 511

[12] ROORD, J. J., L. H. J. RAMAEKERS: Quantification of intrauterine malnutrition. Biol. Neonate 33 (1978) 273

[13] ROORD, J. J., L. H. J. RAMAEkeRS, J. M. A. VAN ENGELSHOVEN: Intrauterine malnutrition and skeletal retardation. Biol. Neonate 34 (1978) 167

[14] SINCLAIR, J. C.: Heat production and thermoregulation in the small-for-date infant. Pediat. Clin. N. Amer. 17 (1970) 147

[15] STOCKHAUSEN, H. B. v., M. STRUVE: Investigation of accelerated metabolic function in small for gestational age infants. Eur. J. Pediatr. 132 (1979) 169

[16] USHER, R. H.: Clinical and therapeutic aspects of fetal malnutrition. Pediat. Clin. N. Amer. 17 (1970) 169

[17] WALTHER, F. J., L. H. J. RAMAEKERS, J. M. A. VAN ENGELSHOVEN: Skeletal maturity at birth and at the age of 3 years of infants malnourished in utero. Early Hum. Dev. 5 (1981) 139

[18] WALTHER, F. J., L. H. J. RAMAEKERS: Developmental aspects of subacute fetal distress: Behaviour problems and neurological dysfunction. Early Hum. Dev., in press

[19] Wirth, F. H., K. E. GOLDBERG, L. O. LUBCHENCO: Neonatal hyperviscosity: I Incidence. Pediatrics 63 (1979) 833

Received July 7, 1981. Accepted August 17, 1981.

Dr. F. J. Walther Dept. of Neonatology St. Annadal Hospital University of Limburg P. O. box 1918 6201 BX Maastricht The Netherlands 